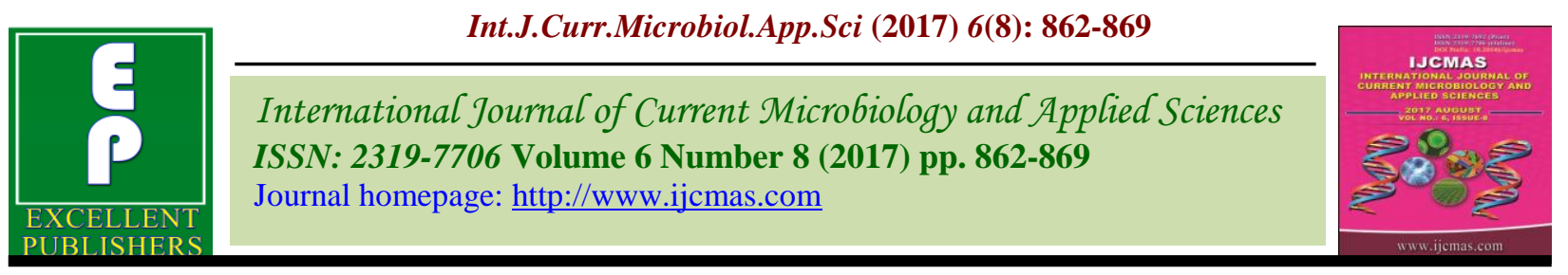

Original Research Article

https://doi.org/10.20546/ijcmas.2017.608.109

\title{
Effect of Pre-Dying Treatments on Production of Quality Dry Flowers in Carnation
}

\author{
S. Sindhuja ${ }^{1 *}$, T. Padmalatha ${ }^{1}$, A.S. Padmavathamma ${ }^{1}$ and A.L.N. $\operatorname{Prasad}^{2}$ \\ ${ }^{1}$ SKL Telangana State Horticultural University, College of Horticulture, \\ Rajendranagar, Hyderabad-30, Telangana, India \\ ${ }^{2}$ Floriculture Research Institute, ARI, Rajendranagar, Hyderabad-30, Telangana, India \\ *Corresponding author
}

\begin{abstract}
Keywords
Carnation,

Steam blanching,

Organic acids,

Dehydration,

Total carotenoid content, Sensory score.

Article Info

Accepted:

14 June 2017

Available Online:

10 August 2017
\end{abstract}

\section{A B S T R A C T}

An experiment was carried out to study the effect of pre drying treatments (steam blanching and organic acids) on production of quality dry flowers in carnation cv. Harvey during the year 2014 at College of Horticulture, Rajendranagar, Hyderabad. The investigation was conducted with nine pre drying treatments viz., $\mathrm{T}_{1}-$ Steam blanching for $1 \mathrm{~min}, \mathrm{~T}_{2}$ - Steam blanching for $2 \mathrm{~min}, \mathrm{~T}_{3}$ - Soaking in citric acid $(0.5 \%)$ for $15 \mathrm{~min}, \mathrm{~T}_{4}$ Soaking in citric acid (1\%) for $15 \mathrm{~min}, \mathrm{~T}_{5}-$ Soaking in ascorbic acid $(0.5 \%)$ for $15 \mathrm{~min}, \mathrm{~T}_{6}$ - Soaking in ascorbic acid (1\%) for $15 \mathrm{~min}, \mathrm{~T}_{7}$ - Soaking in tartaric acid $(0.5 \%)$ for $15 \mathrm{~min}$, $\mathrm{T}_{8}$ - Soaking in tartaric acid (1\%) for $15 \mathrm{~min}$ and $\mathrm{T}_{9-}$ - Control (Soaking in distilled water for $15 \mathrm{~min}$ ) and replicated thrice. Pretreated flowers were embedded in borax + silica gel $(1: 1, \mathrm{v} / \mathrm{v})$ mixture and dried in hot air oven at $55 \pm 1{ }^{\circ} \mathrm{C}$. Data were statistically analyzed in Completely Randomized Design. The study revealed non significant differences with respect to dry flower weight, dry flower diameter, percent moisture loss and time taken to dry. Pre drying treatment of carnation flowers with citric acid $(0.5 \%)$ for 15 minutes recorded maximum score for color (2.97), shape (2.92), texture (3.40), brittleness (3.32), overall acceptability (3.65) and total carotenoid content $(66.30 \mu \mathrm{g} / \mathrm{g})$. Least score for colour (1.95), shape (2.05) and texture (1.99) was observed with flowers treated with steam blanching for 2 min. Least score for brittleness (1.67), overall acceptability (2.05) and total carotenoid content $(21.51 \mu \mathrm{g} / \mathrm{g})$ was noticed with distilled water pre treatment for $15 \mathrm{~min}$.

\section{Introduction}

Flowers have always remained an integral part of man's life and love for natural flowers is an inherent instinct. There is an increasing demand all over the world for the decoration of living and working places with ecofriendly things like fresh foliages and flowers, dried plant parts and dry flowers. Fresh flowers and foliages though exquisite in their beauty, are highly expensive. Also they are perishable and delicate in nature and cannot retain their beauty and fresh look for a long time in spite of using best chemicals for enhancing vase life. Moreover, there is a nonavailability of fresh flowers and foliages all round the year in all places (Datta, 2004). In this context, dried and preserved ornamental products offer a wide range of qualities like novelty, longevity, aesthetic properties, flexibility and year round availability. Dried ornamental plant parts are generally less 
expensive and are sought for their everlasting and attractive appearance. Dried flowers and foliage can be used for making decorative floral segments like wall hangings, landscape calendars, potpourries etc. for various purposes with potpourries being the major segment of drying flower industry valuing at Rs.55 crores in India alone (Murugan et al., 2007). The growing demand for dry flowers is increasing day by day due to change in purchasing power and living habit of the human being in the world. Future prospects of the dry flower industry are expected to contribute a lot in the country's economy in comparison to the fresh cut flowers and other live plants. In the recent floriculture trade, the export of dry flowers from India during 201314 was Rs. 363.3 crores (Perinban et al., 2014). However, in India, we have never looked into the tremendous export potential of dry flower industry and till date it is the most neglected industry. To strengthen the dry flower industry, more research is required so as to promote and uplift the industry. So, there is a need to tune the techniques of drying of flowers with special reference to the available flora and fauna under the conditions prevailing in India. Carnation (Dianthus caryophyllus L.) the 'divine flower' or 'flower of the Gods' is one of the most important cut flower of the world, due to its excellent keeping quality, wide range of forms, ability to withstand long distances even after continuous shipping. But, in India very little organized research work was done in carnation flowers for production of dry flowers. Moreover, change in petal colour (browning or darkening) is common during drying and quality of the produce is poor. Earlier research findings have indicated that pre treatment with organic acids like citric acid, ascorbic acid, tartaric acid or steam blanching have a significant effect in colour and quality retention of fruits (Rabbah et al., 2000; Ndiaye et al., 2009; Thakur et al., 2010), vegetables (Sharma et al., 2000;
Bechoff, 2011) and flowers (Aravinda and Jayanthi, 2004; Liu Ming Jing, 2013) during the dehydration process. Hence, the present investigation was undertaken to explore the possibility of improving the quality of dry flowers with steam blanching and organic acids pre-drying treatment.

\section{Materials and Methods}

The experiment was carried out at College of Horticulture, Rajendranagar, Hyderabad from August to November, 2014. In the present study, nine pre drying treatments viz., $\mathrm{T}_{1}$ Steam blanching for $1 \mathrm{~min}, \mathrm{~T}_{2}$ - Steam blanching for $2 \mathrm{~min}, \mathrm{~T}_{3}$ - Soaking in citric acid $(0.5 \%)$ for $15 \mathrm{~min}, \mathrm{~T}_{4}-$ Soaking in citric acid (1\%) for $15 \mathrm{~min}, \mathrm{~T}_{5}$ - Soaking in ascorbic acid $(0.5 \%)$ for $15 \mathrm{~min}, \mathrm{~T}_{6}$ - Soaking in ascorbic acid (1\%) for $15 \mathrm{~min}, \mathrm{~T}_{7}$ - Soaking in tartaric acid $(0.5 \%)$ for $15 \mathrm{~min}, \mathrm{~T}_{8}$ - Soaking in tartaric acid $(1 \%)$ for $15 \mathrm{~min}$ and $\mathrm{T}_{9^{-}}$ Control (Soaking in distilled water for 15 min) were evaluated in Completely Randomized Design with three replications. The healthy, disease free and uniform flower stems of carnation cv. Harvey were harvested at the commercial stage (ray florets $3 / 4^{\text {th }}$ opened) in the morning hours between 8.00 and $9.00 \mathrm{am}$. Immediately after harvest, the cut ends of the flower stalks were placed in distilled water and brought to the laboratory of the department. The stem length of the each flower was kept at a uniform length of 6 $\mathrm{cm}$. The leaves present on each cut stem were removed. Steam blanching was performed under atmospheric condition in a household pan filled with water and heated by a hot plate. One layer of the flowers was put on a tray made of stainless steel mesh. When water was at a rolling boil, the tray with flowers was put in the pan and covered with a lid as soon as possible. One (or) two minutes later as per the treatments the tray was removed from the pan quickly and the flowers were allowed to cool down to room temperature naturally. For 
organic acid treatments, flowers were soaked in the organic acid solutions according to the treatments. Then, flowers were taken out from the solution, water was drained out by placing the flowers on a fine cloth and allowed to air dry until the water was evaporated. After subjecting to the pretreatments, flowers were placed in the embedding medium (borax + silica gel, 1:1 v/v). Plastic containers $(14 \mathrm{~cm}$ height and $14 \mathrm{~cm}$ diameter) with lid were used for filling the embedding medium. About one inch layer of the desiccant was poured into the bottom of container and the flower stems were pushed into the medium. Desiccant was then gently and gradually poured all around and over the flower up to 4 to $5 \mathrm{~cm}$ above, so as to fill all the crevices in between the petals without disturbing the shape of flowers. The containers were kept in a hot air oven and dried at $55 \pm 1{ }^{\circ} \mathrm{C}$. After dehydration, the containers were tilted for removing the desiccant over and around the flowers. The dried flowers were picked up by hand, cleaned by inverting them and tapping the stems with fingers slowly and gently. Remaining desiccant was finally removed with the help of fine brush. Observations on flower fresh weight, dry weight, dry flower diameter, per cent moisture loss, and time taken to dry were recorded.

\section{Estimation of total carotenoid content}

Total carotenoid content was determined by following the procedure outlined by Zakaria et al., 1979 as detailed below.

\section{Saponification}

Take $1 \pm 0.5 \mathrm{~g}$ of homogenized sample in a 100 $\mathrm{ml}$ conical flask and dissolve in $10 \mathrm{ml}$ of working alcoholic $\mathrm{KOH}$ solution freshly prepared before analysis. Incubate the flask at $37^{\circ} \mathrm{C}$ for $30 \mathrm{~min}$, shaking intermittently. Transfer the contents to a separating funnel for extraction.

\section{Extraction of total carotenoids}

Extract the saponified mixture with petroleum ether. Use $50 \mathrm{ml}$ of the solvent for each extraction in a separating funnel. Pool the upper solvent layer after each extraction in a separate $250 \mathrm{ml}$ conical flask. Transfer the lower alcohol layer back to the separating funnel for next extraction.

Repeat the process for 3-4 times or until a clear white layer is obtained indicating complete extraction. Pour the pooled petroleum ether layer into the separating funnel after discarding the lower layer and wash three times with distilled water. Dispense the washed solvent into a conical flask and add 20-30 g of anhydrous sodium sulphate to remove excess water. Transfer the solvent to a $100 \mathrm{ml}$ measuring cylinder, volume " $y$ " is measured and noted and OD of the solution ( $\mathrm{x}$ ) is measured at a wavelength of $450 \mathrm{~nm}$ in a spectrophotometer (UV- VIS, CE 7400).

\section{Observations}

O.D of the sample, $\mathrm{x}=$

Volume of the pooled extract, $y=$---------- $\mathrm{ml}$ Sample wt., $\mathrm{z}=$-------------- $\mathrm{g}$

\section{Calculations}

$1 \mathrm{OD}=4 \mu \mathrm{g} / \mathrm{ml}(10000 / 2500)$

" $\mathrm{x}$ " $\mathrm{OD}=4 \mathrm{x} \mathrm{X} \mu \mathrm{g}$

" $\mathrm{y}$ " ml contains $4 \mathrm{X}$ x Xy $\mu \mathrm{g}$ of total carotenes $4 \mathrm{xy} \mu \mathrm{g}$ is derived from ' $\mathrm{z}$ 'mg sample



\section{Results and Discussion}

Total carotenoids in $\mu \mathrm{g}$ per 100 grams of the given sample. 
A panel of five judges assessed the quality parameters viz., color, shape, texture, brittleness and overall acceptability by scoring on a five-point scale i.e. excellent, very good, good, bad and very bad with the weightage of 3.5-4.0, 2.5-3.4, 1.5-2.4, 0.5-1.4 and 0.0-0.4 respectively. The data were analyzed in CRD as per the procedure out lined by Panse and Sukhatme, 1985.

Data pertaining to carnation dry flower weight, dry flower diameter, per cent moisture loss and time taken to dry as influenced by pre-drying treatment with steam blanching and organic acids had revealed non significant differences (Tables 1 and 2).

Colour of the dried carnation flowers was significantly influenced by the pre-drying treatments (Table 3). Maximum score for colour was recorded when flowers of cv. Harvey were treated with citric acid $(0.5 \%)$ for $15 \mathrm{~min}$ (2.97) followed by tartaric acid (1\%) treatment for $15 \mathrm{~min}$ (2.72). Similar results were found by Aravinda and Jayanthi (2004) in chrysanthemum and Abdulla et al., (2014) in sweet potato chips where, pre treatment with citric acid scored maximum points for colour after drying. Wan Kun (2012) found that in pink carnation flowers, pre-soaking in $1 \%$ citric acid solution for 45 min followed by drying in hot air oven with silica gel embedding was best method of colour keeping. Sowbhagya et al., (2013) reported that pre-treatment of marigold flowers with citric acid resulted in significant improvement in pigment yield as compared to control sample. A group of enzymes, collectively called "phenolase" is responsible for browning. This type browning is a serious problem during the dehydration process where any injury to the plant tissue, sustained through the use of heat, can result in phenolase activation. The optimum $\mathrm{pH}$ of phenolase lies within the range 6-7, and below 3 there is virtually no enzymatic activity. In general the action of organic acids is to lower tissue $\mathrm{pH}$ and thus to decrease the rate of enzymatic browning. Citric acid has long been used as a chemical inhibitor of enzymatic browning (Ndiaye et al., 2009; Thakur et al., 2010). Citric acid possesses a double inhibitory effect on phenolase, not only by lowering the $\mathrm{pH}$ of the medium, but also by chelating with the copper moiety of the enzyme. Thus, it could be attributed that citric acid acts as an anti oxidant and prevented the browning of carnation flowers due to dehydration. Least score for colour was observed with flowers of cv. Harvey treated with steam blanching for 2 min (1.95).

The sensory score for shape as influenced by pre-drying treatments is presented in table 3. Significant differences were observed among the pre-drying treatments on flower shape. $\mathrm{Cv}$. Harvey treated with citric acid $(0.5 \%)$ for 15 min recorded maximum score for shape (2.92) followed by flowers of cv. Harvey treated with tartaric acid (1\%) for $15 \mathrm{~min}$ (2.71). Least score for shape was noticed when flowers of cv. Harvey treated with steam blanching for two min (2.05) and was on par with steam blanching for 1 min (2.13). Aravinda and Jayanthi (2004) and Abdulla et al., (2014) reported maximum points for shape of dried chrysanthemum flowers and sweet potato chips respectively with citric acid pre-drying treatment.

Significant differences were observed due to pre-drying treatments with respect to texture of dried carnation flowers (Table 3). Maximum score for texture (3.40) was recorded when flowers of cv. Harvey were pre treated with citric acid $(0.5 \%)$ for $15 \mathrm{~min}$ followed by tartaric acid (1\%) treatment for $15 \mathrm{~min}$ (2.30). Similar results with regard to texture were reported by Aravinda and Jayanthi (2004) in chrysanthemum flowers and Abdulla et al., (2014) in sweet potato chips with citric acid as the pre drying 
treatment. Least score for texture was noticed for flowers of cv. Harvey treated with steam blanching for $2 \mathrm{~min}$ (1.99).

A perusal of data on brittleness of carnation flowers due to pre drying treatments (Table 4) revealed that maximum score was recorded with flowers of cv. Harvey treated with citric acid $(0.5 \%)$ for $15 \mathrm{~min}$ (3.32). Abdulla et al.,
(2014) also obtained maximum score for brittleness in sweet potato chips with citric acid as the pre drying treatment. Least score for brittleness was noticed when flowers of cv. Harvey treated with distilled water for 15 min (1.67). The data pertaining to overall acceptability of dried carnation flowers as influenced by the pre-drying treatments (Table 4) indicated that flowers of $\mathrm{cv}$.

Table.1 Effect of pre-drying treatments (steam blanching and organic acids) on dry flower weight $(\mathrm{g})$ and dry flower diameter $(\mathrm{cm})$ in carnation cv. Harvey

\begin{tabular}{|c|c|c|}
\hline Treatments $(\mathbf{T})$ & $\begin{array}{c}\text { Dry flower } \\
\text { weight } \\
\text { (g) }\end{array}$ & $\begin{array}{c}\text { Dry flower } \\
\text { diameter }(\mathrm{cm})\end{array}$ \\
\hline $\mathrm{T}_{1}$ - Steam blanching for $1 \mathrm{~min}$ & 1.64 & 3.44 \\
\hline $\mathrm{T}_{2}$ - Steam blanching for $2 \mathrm{~min}$ & 1.76 & 3.62 \\
\hline $\mathrm{T}_{3}$ - Soaking in citric acid $(0.5 \%)$ for $15 \mathrm{~min}$ & 1.72 & 3.52 \\
\hline $\mathrm{T}_{4}-$ Soaking in citric acid (1\%) for $15 \mathrm{~min}$ & 1.64 & 3.61 \\
\hline $\mathrm{T}_{5}$ - Soaking in ascorbic acid $(0.5 \%)$ for $15 \mathrm{~min}$ & 1.73 & 3.45 \\
\hline $\mathrm{T}_{6}-$ Soaking in ascorbic acid $(1 \%)$ for $15 \mathrm{~min}$ & 1.66 & 3.56 \\
\hline $\mathrm{T}_{7}-$ Soaking in tartaric acid $(0.5 \%)$ for $15 \mathrm{~min}$ & 1.69 & 3.57 \\
\hline $\mathrm{T}_{8}-$ Soaking in tartaric acid (1\%) for $15 \mathrm{~min}$ & 1.77 & 3.47 \\
\hline $\mathrm{T}_{9}-$ Control (Soaking in distilled water for $15 \mathrm{~min}$ ) & 1.65 & 3.52 \\
\hline S.Em \pm & 0.04 & 0.05 \\
\hline CD at $5 \%$ & NS & NS \\
\hline
\end{tabular}

Table.2 Effect of pre-drying treatments (steam blanching and organic acids) on per cent moisture loss (\%) and time taken to dry (hours) in carnation cv. Harvey

\begin{tabular}{|c|c|c|}
\hline Treatments $(\mathrm{T})$ & $\begin{array}{c}\text { Per cent } \\
\text { moisture loss } \\
(\%)\end{array}$ & $\begin{array}{c}\text { Time taken to } \\
\text { dry } \\
\text { (hours) }\end{array}$ \\
\hline $\mathrm{T}_{1}$ - Steam blanching for $1 \mathrm{~min}$ & 76.11 & 43.25 \\
\hline $\mathrm{T}_{2}$ - Steam blanching for $2 \mathrm{~min}$ & 75.77 & 43.38 \\
\hline $\mathrm{T}_{3}-$ Soaking in citric acid $(0.5 \%)$ for $15 \mathrm{~min}$ & 74.28 & 44.06 \\
\hline $\mathrm{T}_{4}$ - Soaking in citric acid (1\%) for $15 \mathrm{~min}$ & 74.31 & 43.87 \\
\hline $\mathrm{T}_{5}$ - Soaking in ascorbic acid $(0.5 \%)$ for $15 \mathrm{~min}$ & 76.21 & 44.00 \\
\hline $\mathrm{T}_{6}-$ Soaking in ascorbic acid (1\%) for $15 \mathrm{~min}$ & 74.63 & 44.50 \\
\hline $\mathrm{T}_{7}-$ Soaking in tartaric acid $(0.5 \%)$ for $15 \mathrm{~min}$ & 74.25 & 43.09 \\
\hline $\mathrm{T}_{8}-$ Soaking in tartaric acid (1\%) for $15 \mathrm{~min}$ & 76.03 & 43.25 \\
\hline $\mathrm{T}_{9}-$ Control (Soaking in distilled water for $15 \mathrm{~min}$ ) & 74.57 & 43.88 \\
\hline S.Em \pm & 0.64 & 0.53 \\
\hline CD at $5 \%$ & NS & NS \\
\hline
\end{tabular}


Table.3 Effect of pre-drying treatments (steam blanching and organic acids) on colour, shape and texture of dried carnation cv. Harvey as assessed through sensory evaluation

\begin{tabular}{|l|c|c|c|}
\hline Treatments (T) & Colour & Shape & Texture \\
\hline $\mathrm{T}_{1}$ - Steam blanching for 1 min & 2.12 & 2.13 & 2.25 \\
\hline $\mathrm{T}_{2}$ - Steam blanching for 2 min & 1.95 & 2.05 & 1.99 \\
\hline $\mathrm{T}_{3}$ - Soaking in citric acid (0.5\%) for 15 min & 2.97 & 2.92 & 3.40 \\
\hline $\mathrm{T}_{4}$ - Soaking in citric acid (1\%) for 15 min & 2.30 & 2.19 & 2.07 \\
\hline $\mathrm{T}_{5}$ - Soaking in ascorbic acid (0.5\%) for 15 min & 2.25 & 2.16 & 2.25 \\
\hline $\mathrm{T}_{6}$ - Soaking in ascorbic acid (1\%) for 15 min & 2.40 & 2.28 & 2.12 \\
\hline $\mathrm{T}_{7}$ - Soaking in tartaric acid (0.5\%) for 15 min & 2.05 & 2.20 & 2.05 \\
\hline $\mathrm{T}_{8}$ - Soaking in tartaric acid (1\%) for 15 min & 2.72 & 2.71 & 2.30 \\
\hline $\mathrm{T}_{9}$ - Control (Soaking in distilled water for 15 & & & 2.10 \\
min) & 2.17 & 2.14 & 0.04 \\
\hline S.Em \pm & 0.05 & 0.18 & 0.13 \\
\hline CD at 5\% & 0.15 & 0.53 & \\
\hline
\end{tabular}

Table.4 Effect of pre-drying treatments (steam blanching and organic acids) on brittleness, overall acceptability and total carotenoids $(\mu \mathrm{g} / \mathrm{g})$ of dried carnation cv. Harvey

\begin{tabular}{|l|c|c|c|}
\hline Treatments (T) & Brittleness & $\begin{array}{c}\text { Overall } \\
\text { acceptability }\end{array}$ & $\begin{array}{c}\text { Total } \\
\text { carotenoids } \\
(\boldsymbol{\mu g} / \mathbf{g})\end{array}$ \\
\hline $\mathrm{T}_{1}$ - Steam blanching for 1 min & 2.20 & 2.32 & 37.86 \\
\hline $\mathrm{T}_{2}$ - Steam blanching for 2 min & 2.07 & 2.12 & 27.29 \\
\hline $\mathrm{T}_{3}$ - Soaking in citric acid $(0.5 \%)$ for 15 min & 3.32 & 3.65 & 66.30 \\
\hline $\mathrm{T}_{4}$ - Soaking in citric acid (1\%) for 15 min & 2.05 & 2.11 & 53.25 \\
\hline $\mathrm{T}_{5}$ - Soaking in ascorbic acid $(0.5 \%)$ for 15 min & 2.25 & 2.35 & 59.40 \\
\hline $\mathrm{T}_{6}$ - Soaking in ascorbic acid (1\%) for 15 min & 1.97 & 2.10 & 21.75 \\
\hline $\mathrm{T}_{7}$ - Soaking in tartaric acid $(0.5 \%)$ for 15 min & 2.12 & 2.20 & 25.50 \\
\hline $\mathrm{T}_{8}$ - Soaking in tartaric acid (1\%) for 15 min & 2.30 & 2.80 & 59.75 \\
\hline $\mathrm{T}_{9}$ - Control (Soaking in distilled water for 15 min) & 1.67 & 2.05 & 21.51 \\
\hline S.Em \pm & 0.05 & 0.05 & 0.69 \\
\hline CD at 5\% & 0.14 & 0.17 & 2.02 \\
\hline
\end{tabular}

Harvey treated with citric acid $(0.5 \%)$ for 15 min recorded significantly maximum score for overall acceptability (3.65) followed by tartaric acid (1\%) treatment for 15 min (2.80). Least score for overall acceptability was noticed when flowers of cv. Harvey were treated distilled water for $15 \mathrm{~min}$ (2.05) and was on par with ascorbic acid (1\%) treatment for $15 \mathrm{~min}$ (2.10). These results are in accordance with the findings of Abdulla et al.,
(2014) who reported that sweet potato chips pre-treated with citric acid had the best sensory score for overall acceptability.

The data on total carotenoid content of carnation flowers as influenced by the predrying treatment with steam blanching and organic acids (Table 4) revealed that the total carotenoid content was significantly affected by the pre-drying treatments. Maximum 
retention of total carotenoids was recorded when flowers of cv. Harvey treated with citric acid $(0.5 \%)$ for $15 \mathrm{~min}(66.30 \mu \mathrm{g} / \mathrm{g})$ followed by cv. Harvey treated with tartaric acid (1\%) for $15 \mathrm{~min}(59.75 \mu \mathrm{g} / \mathrm{g})$. Chemical changes to carotoneoid are caused by heat and oxidation during drying. Citric acid pretreatment will constraint oxidation, inactivate enzymes, micro organisms on surface and carotene is thoroughly protected. Bechoff et al., (2011) noticed a slight improvement in carotenoid content of orange fleshed sweet potato chips with citric acid pre drying treatment. Le Khac Lam Dien et al., (2013) showed that steam blanching of gac fruit (Momordica cochinchinensis) powder with $0.04 \%$ citric acid retained more carotene than control owing to anti-oxidant activity of citric acid. Minimum retention of total carotenoids was observed with distilled water treatment for 15 $\min (21.51 \mu \mathrm{g} / \mathrm{g})$ and was on par with ascorbic acid (1\%) treatment for $15 \mathrm{~min}$ (21.75 $\mu \mathrm{g} / \mathrm{g})$.

The findings from the study showed that drying of pre treated flowers (citric acid $0.5 \%$ for $15 \mathrm{~min}$ ) of carnation cv. Harvey in hot air oven at $55 \pm 1{ }^{\circ} \mathrm{C}$ with borax + silica gel $(1: 1$, $\mathrm{v} / \mathrm{v})$ mixture as the embedding medium could result in better quality dehydrated flowers.

\section{References}

Abdulla, G. Shourbagy, G.A.E. and Sitohy, M.Z. 2014. Effect of pre-drying, blanching and citric acid treatments on the quality of fried sweet potato chips. Ame. J. Food Techn., 9: 39-48.

Aravinda, K. and Jayanthi, R. 2004. Standardization of drying techniques for chrysanthemum

(Dendranthema grandiflora Tzvelev cv. Button Type Local) flowers. J. Orn. Hort., 7: 370375.

Bechoff, A., Westby, A., Menya, G., Keith, I. and Tomlins. 2011. Effect of pretreatments for retaining total carotenoids in dried and stored orangefleshed-sweet potato chips. J. Food Quality, 34: 259-267

Datta, S.K. 2004. Dehydration of flowers: A new diversified product for floriculture industry emerging trends in Ornamental Horticulture. Ind. Soc. Orn. Hort., 157161.

Le Khec Lam Dien, Nguyen Phuoc Minh and Dong Thi Anh Dao. 2013. Investigation on different pretreatment methods and ratio of carrier materials to maintain carotenoids in Gac (Momordica cochinchinensis) powder in drying process. Int. J. Sci. Tech. Res., 2: 360371.

Liu Ming Jing. 2013. A study on chemical color preserving method for pressed dried Rhododendron Pulcherima. South China Agric., 37-39.

Murugan, P.A., Thiyagarajan, G. and Ramesh, K. 2007. Dry flower technology. Website: http://www. Technoprenuer.net/informationdesk/sciencetechmagazine/2007/Dec07/dry flower.pdf.

Ndiaye, C., Xu, S.Y. and Wang, Z. 2009. Steam blanching effect on polyphenol oxidase, peroxidase and colour of mango slices. Food Chem., 113: 92-95.

Panse and Sukhatme, P.V. 1985. Statistical methods for agricultural workers. Indian Council of Agricultural Research, New Delhi.

Perinban, S, Majumder, J., Singh, B., Rai, T. and Kumar, R. 2014. Dried flowers: a new paradigm in Floriculture. http:/www.krishisewa.com/cms/articles/ pht/394-dried-flowers.html.

Rabbah, T.M., Ereifej, K.I. and Howard, L. 2005. Effect of ascorbic acid and dehydration on concentrations of total phenolics, antioxidant capacity, anthocyanins and colour in fruits. Agric. Food Chem., 53: 4444-4447. 
Sharma, G.K., Semwal, A.D. and Arya, S.S. 2000. Effect of processing treatments on the carotenoids composition of dehydrated carrots. J. Food Sci. Techn., 37: 196-200.

Sowbhagya, B.H., Sushma, S.B., Navin, K.R. and Madhava Naidu, M. 2013. Effect of pretreatments on extraction of pigment from marigold flower. Food Sci. Techn., 50: $122-128$

Thakur, N.S., Bhat, M.M., Rana, N. and Joshi, V.K. 2010. Standardization of prtreatments for the preparation of dried arils from wild pomegranate. J. Food Sci. Techn., 47: 620-625.

Wang Kun. 2012. Study on colour keeping technology of some red, pink petals in drying process. J. Anhui Agric. Sci., 3538.

Zakaria, M., Simpson, K., Brown, P. R. and Kostulovic, A. 1979. Use of reversed phase HPLC analysis for the determination of pro vitamin A carotenes in tomatoes. $J$. Chromatography, 176: 109.

\section{How to cite this article:}

Sindhuja, S., T. Padmalatha, A.S. Padmavathamma and Prasad, A.L.N. 2017. Effect of PreDying Treatments on Production of Quality Dry Flowers in Carnation. Int.J.Curr.Microbiol.App.Sci. 6(8): 862-869. doi: https://doi.org/10.20546/ijcmas.2017.608.109 